\title{
Seismology: neotectonics and structure of the Baltic Shield
}

\author{
Søren Gregersen, Martin Glendrup, Tine B. Larsen, Peter Voss and Hans Peter Rasmussen
}

Recent Danish seismological projects involving neotectonic investigations and structural studies have determined the edge of the Baltic Shield underlying Denmark. The most active earthquake zones in Denmark are located in northwestern Jylland and adjoining offshore areas, and in the region around Kattegat, Øresund and north-east Sjælland (Fig. 1). This pattern was originally recognised by Lehmann (1956) and has been confirmed by several later studies, e.g. Gregersen et al. (1998). Recent, more detailed investigations have documented that changes in the pattern of earthquake activity have occurred within a short time span. The most pronounced example of change - possibly related to exploitation of hydrocarbons - is an activity recorded in the Central Graben area of the North Sea that was first documented by Gregersen et al. (1998).

The south-western margin of the Precambrian Baltic Shield separates areas of different earthquake activity (Fig. 1; Gregersen et al. 1991). Although lithospheric stresses are more or less uniform in northern Europe, there are pronounced differences in the behaviour of the lithosphere across Denmark. The north-eastern area underlain by the Baltic Shield experiences brittle failure as recorded by common earthquakes, whereas earthquakes are virtually absent in the region southwest of the shield (Fig. 1).

The margin of the Baltic Shield as defined by earthquake activity is not identical with that distinguished structurally in sedimentary studies (EUGENO-S Working Group 1988; Vejbæk \& Britze 1994), in crustal studies (Abramovitz \& Thybo 2000 ), or by recent studies of the structure of the subcrustal lithosphere (Gregersen et al. 2002; Shomali et al. 2002). The physical edge of the Baltic Shield cannot be uniquely determined on the basis of seismological studies.

The earthquakes recorded, although of low magnitude, do give information about the released stresses. The earthquakes seem to be a response to a dominant NW-SE compression, also apparent elsewhere in Scandinavia and northern Europe
Fig. 1. Computed locations of earthquakes around Denmark during the last 75 years, supplemented by locations provided by the University of Bergen based on arrival time readings from at least five seismograph stations. At shallow depths the south-western boundary of the Baltic Shield coincides with the Sorgenfrei-Tornquist Zone (STZ). CG, Central Graben; EL, Elbe Line; J, Jylland; RFH, Ringkøbing -Fyn High; $\mathbf{S}$, Sjælland; $\varnothing$, Øresund.

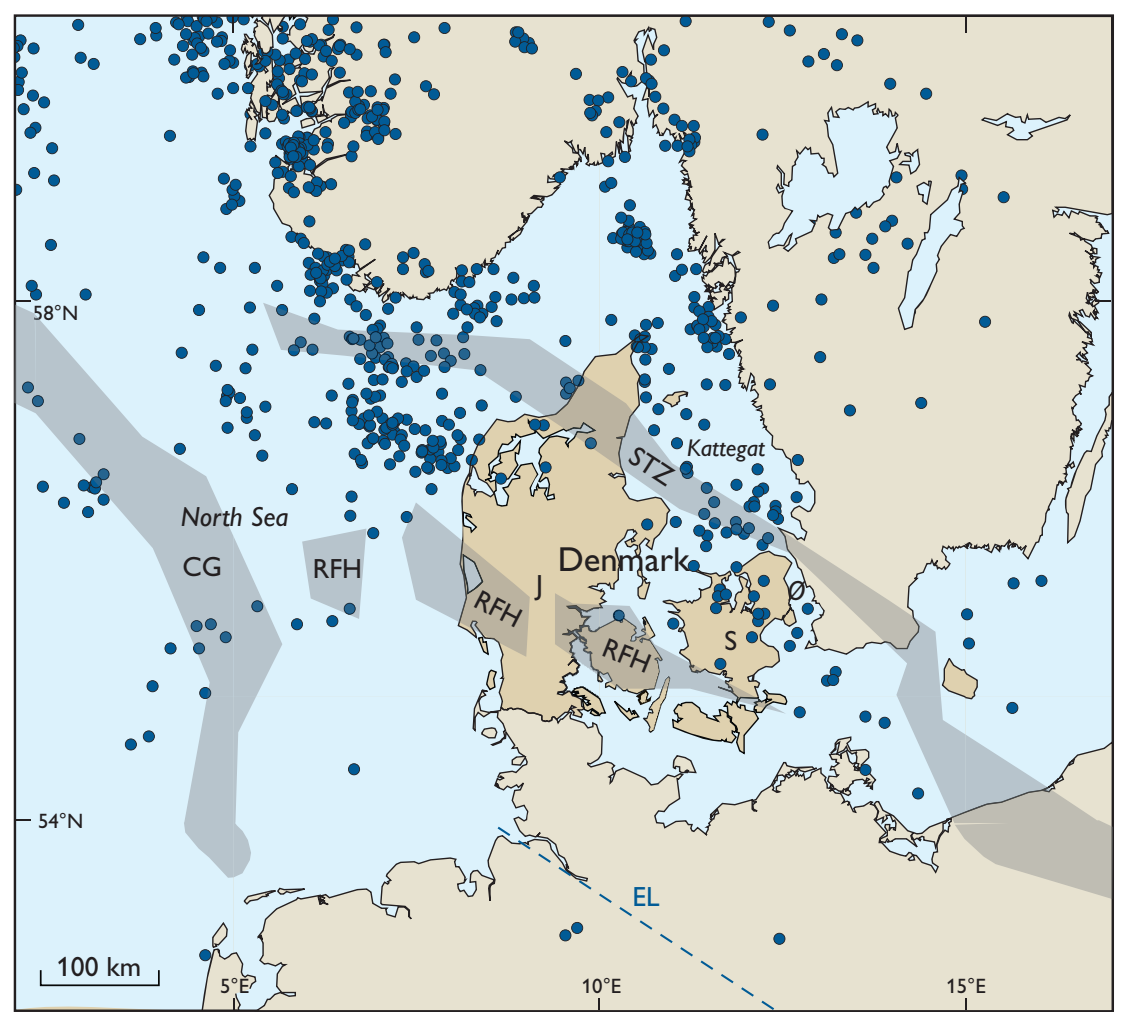




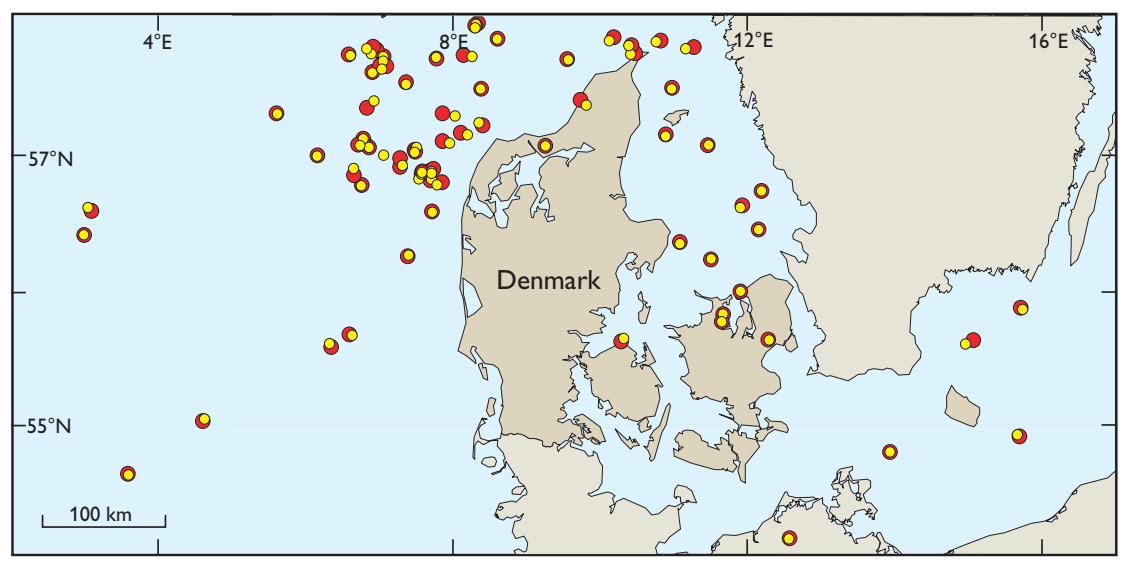

Fig. 2. Comparison of computed earthquake locations for the period 1995-2002, using the HYPOLG software (yellow dots) and the new SeisAn software (red dots).

(Slunga et al. 1984; Slunga 1989; Gregersen 1992; Müller et al. 1992). These stresses are part of the large-scale stress systems associated with continued plate motion pattern (Gregersen \& Basham 1989; Zoback et al. 1989). In contrast to present low-magnitude earthquakes, postglacial sediments in northern Scandinavia have preserved features interpreted as caused by earthquakes of magnitudes around 7; these major, c. 9000 years old earthquakes are believed to be related to the post-glacial uplift of Scandinavia (e.g. Arvidsson et al. 1991; Gregersen 2002).

Earthquakes are always related to fault activity, but attempts to link recent earthquakes occurring in and around Denmark to geologically known faults have only been partly successful (Gregersen et al. 1996). The most significant fault zone in Denmark, the Sorgenfrei-Tornquist Zone, is only locally active. Recent geodetic and seismic investigations demonstrate that the two sides of the Sorgenfrei-Tornquist Zone are characterised by different patterns of deformation, but the zone itself is not defined by a present-day seismicity trend crossing the central parts of Denmark (Fig. 1).

\section{Seismological monitoring in Denmark}

Seismological monitoring in Denmark has until recently been carried out by a staff of four full-time workers and one temporary employee at the Danish National Survey and Cadastre (KMS). This function was transferred to the Geological Survey of Denmark and Greenland (GEUS) in 2004. The monitoring is carried out with four permanent seismographs located in Denmark, and four permanent and ten temporary stations located in Greenland. Currently a technical transfer from analogue to digital data handling is almost complete. This involves changes of the data processing for local earthquake signals and substitution of the earthquake location program by an improved version described below.

The earthquake list covering the Danish area has recently been updated to include all recognised small earthquakes (see www.geus.dk). Supplementary data on earthquakes, which other agencies have located in the Danish area, can be found on the web pages of the University of Bergen in Norway (www.ifff.uib.no/seismologi) and the University of Helsinki in Finland (www.seismo.helsinki.fi).

\section{Recomputation of earthquake locations}

The computer program hitherto used in Denmark for computing earthquake locations (HYPOLG) is a modified version of the globally distributed location program (HYPO71) from the United States Geological Survey (Lee \& Lahr 1972; Gregersen 1979). The current location program (HYPOCENTER) now used at GEUS is that of Lienert et al. (1986) and forms part of the analysis program for digital seismograph data (SeisAn) from the University of Bergen (Havskov \& Ottemöller 1999). The consistency of new and old procedures has been tested by analysis and comparison of all the seismogram records of Danish earthquakes for the period 1995-2002 (Fig. 2).

The input to the two programs is the same. The HYPOLG program has an option for disregarding those readings that are not in agreement with the rest, i.e. have arrival time anomalies larger than three standard errors, while such anomalous readings are preserved and included in the computations in the SeisAn version of HYPOCENTER. This difference has been taken into consideration in the comparison of the two programs, such that the same readings were included in both. The distance between any two computed locations of the same earthquake is typically 2 to $3 \mathrm{~km}$. The largest differences of 7 to $13 \mathrm{~km}$ determined for four earthquakes are due either to few station readings (4-5) or poor azimuth coverage (overweight of readings from a small azimuth interval). The error in location determination for the same earthquake decreases with increased input of more arrival times. 
The results are very satisfactory and the shift to the earthquake location program HYPOCENTER included in SeisAn (Lienert et al. 1986; Lienert \& Havskov 1995) is made for 2003 and the following years. The errors in the locations measured through the root mean square of the travel time anomalies with SeisAn are no higher than $3.1 \mathrm{sec}$. with an average of $1.76 \mathrm{sec}$. HYPOLG has a root mean square average of $1.88 \mathrm{sec}$. for the location of the 76 earthquakes.

\section{Tor project}

A major international teleseismic project implemented in 1996 had the objective of delineating the lithospheric differences and the shape of the edge of the Baltic Shield across the Sorgenfrei-Tornquist Zone. The Tor project (Teleseismic Tomography across the Tornquist Zone) represents a collaboration between geophysical and geological institutes in Sweden, Germany, Poland, France, the Czech Republic, Switzerland, the Netherlands and the USA with Danish leadership (Gregersen et al. 2002). Field work and interpretation studies carried out by most partner institutions were completed in the years 1996-2002, except for a Danish Ph.D. study that is still active.

The Tor seismograph array (Fig. 3) covered areas where extensive seismic crustal studies (i.e. in the depth range 0-60 $\mathrm{km}$ ) over the last two decades have identified a terrane boundary between the ancient plates of Baltica and Avalonia. The Tor project extends below this level into the subcrustal parts of the lithosphere (i.e. depth range $50-300 \mathrm{~km}$ ). Methods of investigation have included studies of $\mathrm{P}$ - and S-wave travel

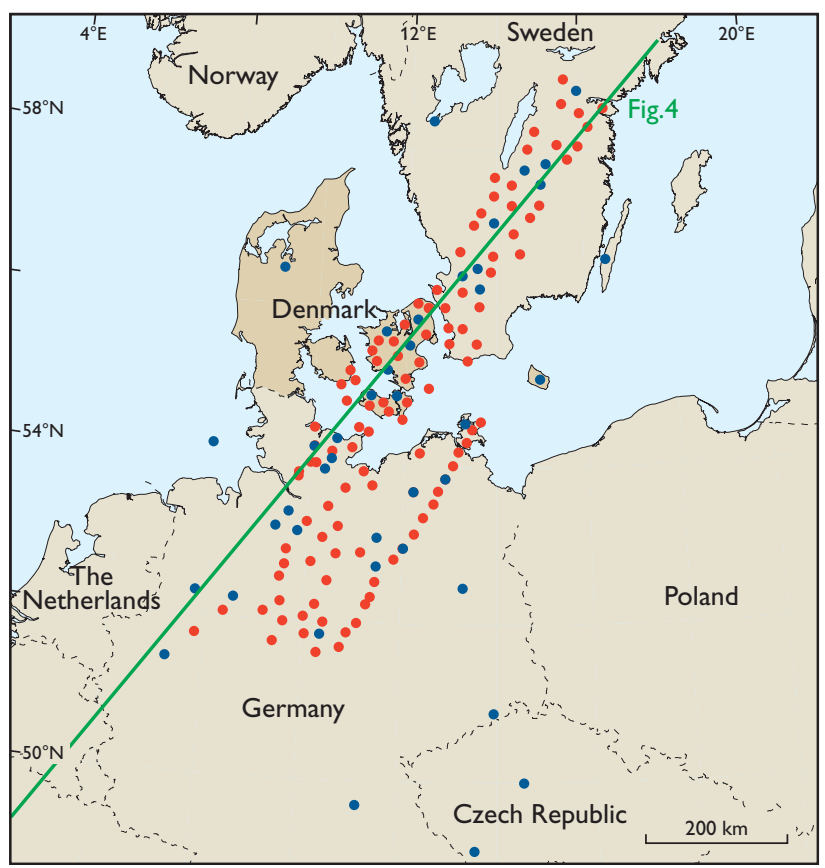

Fig. 3. The locations of seismometers during the field work for the Tor project 1996-1997. Red dots, short period seismographs; blue dots, broad-band seismographs; green line, deep crustal to mantle crosssection shown in Fig. 4.

time tomography, surface wave dispersion, receiver function, SKS splitting and scattering analyses (Shomali et al. 2002).

In the tomographic cross-section (Fig. 4) the local deviations from a homogeneously layered reference model are shown. Sharp and steep boundaries between 'fast' and 'slow'

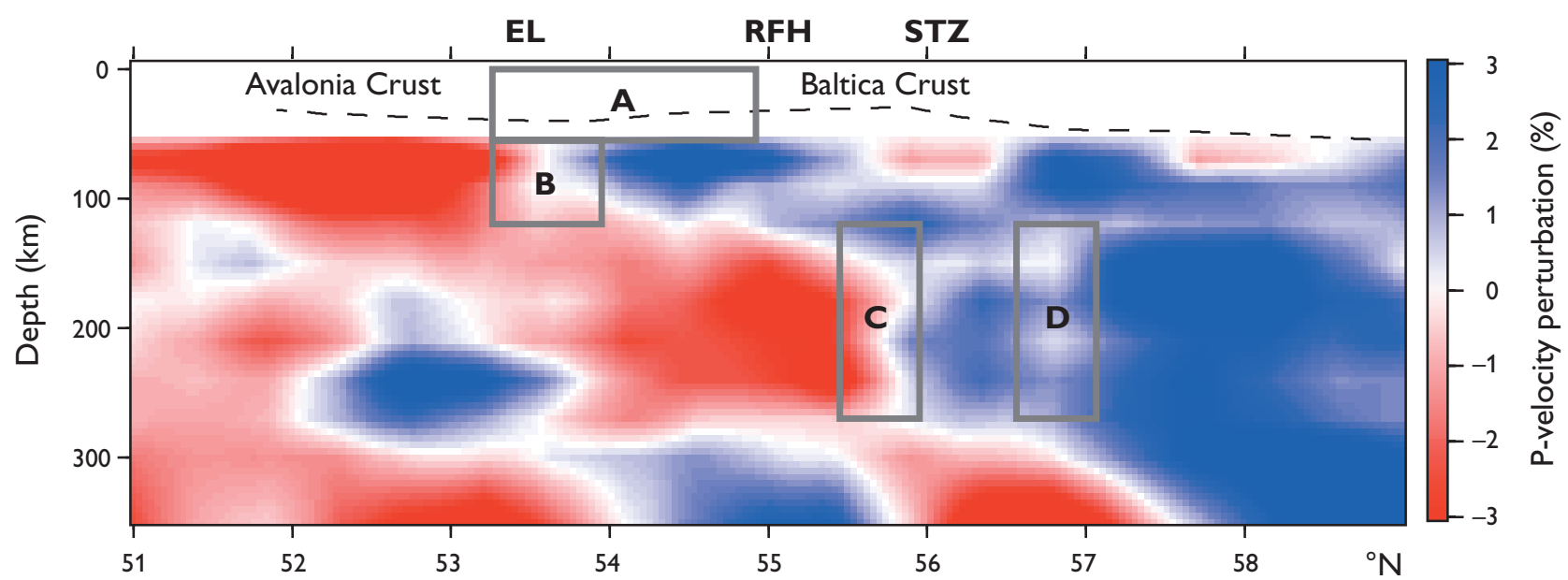

Fig. 4. Deviations in P-wave velocities in a deep crustal to mantle cross-section acquired to a depth of $350 \mathrm{~km}$ during the Tor project (from Shomali et al. 2002). For location of line see Fig. 3. The colouring indicates velocities lower (red) or higher (blue) than the average at any level. The edge of the Baltic Shield as defined by sedimentary basin studies is located by the Sorgenfrei-Tornquist Zone (STZ). However, crustal transition occurs gradually within frame A between the Ringkøbing-Fyn High (RFH) and the Elbe Line (EL). A subcrustal transition occurs within frame B, and another pronounced and steep transition occurs in frame $\mathbf{C}$, roughly coinciding with the STZ. A third, deep and less pronounced lithospheric transition occurs beneath the Baltic Shield in frame $\mathbf{D}$ 
lithosphere are seen as changes from red to blue in frames B and C, and the change from light blue to dark blue (frame D). Together these boundaries represent a major change in the lithosphere between the Precambrian shield in Scandinavia and areas dominated by Phanerozoic deposits in central Europe. Although temperatures and pressures are large at the investigated depths, it should be noted that the changes are stepwise and not gra-dual, as might be expected.

The disparity in the position of the edge of the shield as defined at shallow crustal levels in the flanking sedimentary basins by the Sorgenfrei-Tornquist Zone, and that at deep crustal and subcrustal levels is significant. Recent crustal studies have indicated that the transition occurs somewhere between the Elbe Line and the Ringkøbing-Fyn High (Fig. 4, frame A; Abramovitz \& Thybo 2000). The subcrustal lithosphere edges revealed by the Tor investigations (in frames B, C and D of Fig. 4) appear to be related to the shallow crustal transitions. However, the actual relationships between the changes observed at shallow and deep crustal levels are not well understood, and further geophysical studies are desirable.

\section{References}

Abramovitz, T. \& Thybo, H. 2000: Seismic images of Caledonian lithosphere-scale collision structures in the southeastern North Sea along MONA LISA Profile 2. Tectonophysics 317, 27-54.

Arvidsson, R., Gregersen, S., Kulhanek, O. \& Wahlström, R. 1991: Recent Kattegat earthquakes - evidence of active intraplate tectonics in southern Scandinavia. Physics of the Earth and Planetary Interiors 67, $275-287$.

EUGENO-S Working Group 1988: Crustal structure and tectonic evolution of the transition between the Baltic Shield and the North German Caledonides (the EUGENO-S Project). Tectonophysics 150, 253-348.

Gregersen, S. 1979: Earthquakes in the Skagerrak recorded at small distances. Bulletin of the Geological Society of Denmark 28, 5-9.

Gregersen, S. 1992: Crustal stress regime in Fennoscandia from focal mechanisms. Journal of Geophysical Research 97, 11821-11827.

Gregersen, S. 2002: Earthquakes and change of stress since the ice age in Scandinavia. Bulletin of the Geological Society of Denmark 49 , $73-78$.
Gregersen, S. \& Basham, P.W. (eds) 1989: Earthquakes at North-Atlantic passive margins: neotectonics and postglacial rebound, $716 \mathrm{pp}$. Dordrecht: Kluwer Academic Press.

Gregersen, S., Korhonen, H. \& Husebye, E.S. 1991: Fennoscandian dynamics: presentday earthquake activity. Tectonophysics 189, 333-334.

Gregersen, S., Leth, J., Lind, G. \& Lykke-Andersen, H. 1996: Earthquake activity and its relationship with geologically recent motion in Denmark. Tectonophysics 257, 265-273.

Gregersen, S., Hjelme, J. \& Hjortenberg, E. 1998: Earthquakes in Denmark. Bulletin of the Geological Society of Denmark 44, 115-127.

Gregersen, S., Voss, P., Shomali, Z.H. \& Tor Working Group 2002: Summary of Project Tor: delineation of a stepwise, sharp, deep lithosphere transition across Germany-Denmark-Sweden. Tectonophysics $\mathbf{3 6 0}$, $61-73$.

Havskov, J. \& Ottemöller, L. 1999: SeisAn earthquake analysis software. Seismological Research Letters 70, 532-534.

Lee, W.H.K. \& Lahr, J.C. 1972: HYPO71: a computer program for determining hypocenter, magnitude, and first motion pattern of local earthquakes. U.S. Geological Survey Open File Report 72-224, 100 pp.

Lehmann, I. 1956: Earthquakes in Denmark. Bulletin of the Geological Society of Denmark 13, 88-103 (in Danish with abstract in English).

Lienert, B.R. \& Havskov, J. 1995: A computer program for locating earthquakes both locally and globally. Seismological Research Letters 66(5), 26-36.

Lienert, B.R., Berg, E. \& Frazer, L.N. 1986: HYPOCENTER: an earthquake location method using centered, scaled, and adaptively damped least squares. Bulletin of the Seismological Society of America 76, 771-783.

Müller, B., Zoback, M.L., Fuchs, K., Mastin, L., Gregersen, S., Pavoni, N., Stephansson, O. \& Ljunggren, C. 1992: Regional patterns of tectonic stress in Europe. Journal of Geophysical Research 97, 11783-11803.

Shomali, Z.H., Roberts, R.G. \& Tor Working Group 2002: Non-linear body wave teleseismic tomography along the TOR array. Geophysical Journal International 148, 562-574.

Slunga, R.S. 1989: Focal mechanisms and crustal stresses in the Baltic Shield. In: Gregersen, S. \& Basham, P.W. (eds): Earthquakes at NorthAtlantic passive margins: neotectonics and postglacial rebound, 261 -276. Dordrecht: Kluwer Academic Press.

Slunga, R., Norrman, P. \& Glans, A.-C. 1984: Seismicity of southern Sweden, 106 pp. Stockholm: Forsvarets Forskningsanstalt.

Vejbæk, O.V. \& Britze, P. (compilers) 1994: Geological map of Denmark, 1:750000. Top pre-Zechstein (two-way travel time and depth). Danmarks Geologiske Undersøgelse Kortserie 45, 8 pp.

Zoback, M.L. et al. 1989: Global patterns of tectonic stress. Nature 341, 291-298.

\section{Authors' address}

Geological Survey of Denmark and Greenland, Øster Voldgade 10, DK-1350 Copenhagen K, Denmark. E-mail: sg@geus.dk 